Etnolingual Vol 3 No 1

Mei, 2019, 1-12

\title{
FICTITIOUS STORY OF INDEPENDENT WOMEN: ANALYSIS OF MAIN CHARACTERS' ROLES IN NEW DISNEY PRINCESS MOVIES
}

\author{
Dita D. Palupi \\ ditadpalupi@gmail.com \\ Master of Linguistics, Faculty of Humanities, Universitas Airlangga
}

\begin{abstract}
The former Disney Princess movies mostly, if not all, represent women as the ones who are helpless and require men to save them. However, this representation of women is then altered by Disney, who eventually attempts to change the representation of women into the ones who are independent and able to do things by themselves. This study aims to inspect the similarities in three new Disney Princess movies; Tangled (2010), Frozen (2013), Moana (2016), particularly in the main characters' roles and the princesses' independent acts. The theory of characters of fairy tales (Propp, 1968) is employed in investigating the characters in the movies, then the theory of feminism (Tyson, 2006) is utilized in observing the role of princess characters in the movies. The results demonstrate that there are three main roles in the movies, which are the princess who conducts the quest, the hero who assists the princess in conducting the quest, and the villain who attempts to seize the advantage from the princess. From this result, it can be concluded that although Disney attempts to represent its princesses as the independent women, it still does not let the princesses conduct their quest without any help from men. This is caused by the lack of self-confidence they suffer as women, who mostly think that they are not as good as men in accomplishing a quest.
\end{abstract}

Keywords: character's role, Disney princess, fairy tales, feminism, gender roles

\begin{abstract}
Abstrak
Kebanyakan film Putri-putri Disney, meski tidak semuanya, menggambarkan sosok perempuan yang lemah dan butuh pertolongan pria. Meskidemikian, penggambaran perempuan dalam film Disney belakangan mulai berubah. Mereka kini berusaha menggambarkan sosok perempuan yang mandiri. Kajian ini bertujuan untuk meneliti kesamaan di antara tiga film baru Disney; Tangled (2010), Frozen (2013), dan Moana (2016), terutama peran dari tokoh utamanya dan kemandirian sang Putri. Teori tentang karakter dalam dongeng (Propp, 1968) digunakan untuk menginvestigasi tokoh-tokoh dalam film tersebut. Selanjutnya, teori feminisme (Tyson, 2006) dipakai untuk mengobservasi peran sang Putri dalam film-film tersebut. Hasilnya menunjukkan ada tiga peran utama dalam film-film tersebut, antara lain sang Putri yang mengadakan petualangan, pahlawan yang akan menolong dalam petualangan itu, serta penjahat yang ingin memanfaatkan kesempatan itu dengan licik. Dari hasil ini, dapat disimpulkan bahwa meskipun Disney berusaha menggambarkan sang Putri sebagai wanita yang mandiri, ia masih tidak bisa menyelesaikan petualangannya itu tanpa bantuan laki-laki. Hal ini diakibatkan oleh kurangnya rasa percaya diri mereka sebagai perempuan. Kebanyakan mereka berpikir bahwa mereka tidak sebaik laki-laki dalam menyelesaikan petualangan mereka.
\end{abstract}

Keywords: peran karakter, Putri Disney, dongeng, feminisme, peran gender

\section{INTRODUCTION}

Disney Princess is the legendary media franchise The Walt Disney Company 
has ever created. The media franchise alone gained $\$ 3$ billion in worldwide sales in 2012, making it as the best-selling entertainment product ( $\mathrm{Ng}, 2013)$. This media franchise does not only create movies, but it also provides many trinkets and stuff related to each princess it has (Wohlwend, 2007). Aiming to young girls as the main audience, Disney Princess also attracts audiences from the different range of ages with its sparkly fairy tales. It promises dreams, hopes, and happiness in each story, and pledges the happily-ever-after endings for the harmed princesses. One of the most crucial elements in a story, especially in fairy tales, it must contain characters or leastwise a main character (Renkema, 2004:197). In the fairy tales, there are seven characters that commonly appear along with the story, either in the beginning, in the middle, or at the end of the story. These characters are the villain, the hero, the donor, the helper, the dispatcher, the princess or someone to look for, and the false hero (Propp, 1968). These characters possess their own particularities which liven up each scene of the story. The villain focuses on disturbing other characters' peaceful lives and causing some damage by either destroying or snatching things from others. The villains can take the form of ordinary people if they do not have any magical power, such as Cinderella's stepmother and wicked sisters (Cinderella, 1950), or other creatures if they own any magical power, such as The Evil Queen (Snow White and the Seven Dwarfs, 1937), Maleficent (Sleeping Beauty, 1959), and Ursula the Sea Witch (The Little Mermaid, 1989) (Propp, 1968:27). They will later be defeated by a hero.

The hero is the character who saves the day, the one who will vanquish the villain, rescue the princess and marry her as the reward. In Disney princess movies, the heroes are most likely the princess, like Prince Philip (Sleeping Beauty, 1959), The Beast (Beauty and the Beast, 1991), and Aladdin (1992). In the middle of the journey, the heroes will be assisted by the donor and the helper whom they accidentally encounter somewhere (Propp, 1968:39). The donor is the character who will be encountered by the hero to eventually help the hero accomplish his quest. Similar to the villain, the donors may or may not possess any magical power, such as Fairy Godmother (Cinderella, 1950). They normally test the heroes before eventually granting the hero with the helper to see whether the heroes are worthy of receiving the helper (Propp, 1968:40). If the heroes pass the test, the donors will hand them something to assist them along the journey, which is known as the helper. The helpers, often being referred to as magical agents, can be in the forms of animals, objects containing magical helpers, magical objects, or given power (pp. 43-44).

The heroes occasionally wander away at the behest of a character called the dispatcher. The dispatchers serve to dispatch the hero in executing the quest, hence the name (Propp, 1968:76). The dispatchers can be the heroes' family members or even the princess' father, the king, to resolve a problem or finish a goal, such as saving the princess. Thus, the princess or the person sought for is the character who is required to be rescued, and the hero will marry her as the reward (p. 79). The Disney 
princesses belong to this category. However, when the heroes already accomplish a mission demanded by the dispatcher, another character might take credit for what they have achieved. The character is a false hero. This character claims to be the one who undertakes what the heroes actually carry out (p. 60). The false heroes sometimes attempt to marry the princess or acquire the appreciation they do not deserve. Yet, their disguise will somehow be disclosed due to the things they are incapable of, such as the unaccomplished task that is commanded to them (p. 62).

Since Snow White and the Seven Dwarfs (1937), Disney depicts its princess as domestic women who are nurturing, helpful, submissive, and staying at home all day to do house chores (Erum, n.d.). The story also represents the princesses as the weak women who need to be rescued by men, and marriage becomes the solution to escape from the grief they suffer from (Morrison, 2014). These depictions of women with the princesses' roles in the story are the representations of the traditional gender roles and patriarchal ideology. Feminists extremely against patriarchy and traditional gender roles, in which they point out that it is the society that determines the feminine and masculine behaviors (Tyson, 2006:86). They do not agree with how women are shown in the movies. Disney is the one who should be responsible for influencing how young girls all over the world want to be like (Gazda, 2015). The more they consume Disney princess stuff and watch more Disney princess movies, their identities will more likely to be shaped in accordance with the princesses (Wohlwend, 2007). The expectation of being one of the Disney princesses is dangerous since it affects how the young girls think that it is normal if women are represented this way; being weak and dominated by men (Maity, 2014).

However, nowadays, Disney attempts to create the movies which depicts the princesses who are strong and independent, such as Tangled (2010), Frozen (2013), and Moana (2016). This attempt is welcomed by many audiences, especially feminists. For most feminists, Tangled, Frozen, and Moana are the advancement Disney produces since the movies promote the independent princesses, the quality that most, if not all, of the former princesses, have to live without (Brockmann, 2014; Khalid, 2015; Streiff and Dundes, 2017). Ever since the release, these movies keep surprising the audience with the unusual behaviors the princesses demonstrate along the story, and the audience agrees that this is the movies Disney supposes to make and this is how Disney supposes to depict their princesses that, instead of being beautiful, waiting for their princes, and hoping for marriage to save their lives, they save other people's lives and do not be selfish of their own desire (Maity, 2014). Such advancement is supported by many audiences since Disney targets young girls in creating the princess movies, by which is believed that how Disney depicts their princesses will affect the way these young girls behave (Maity, 2014).

Many researchers agree to declare that Tangled, Frozen, and Moana can be considered as the movies with strong feminism message in them. Khalid (2015) 
argued that Tangled demolishes gender equality and sexism by depicting the more independent role of both the princess and the hero. This movie also attempts to disrupt the binary oppositions of good and evil by the representation of Mother Gothel. Then, Brockmann (2014) tried to collect many opinions about Frozen, and she found some opinions which believe that Frozen is the revolutionary for feminist glory, yet she also detected other opinion saying that it is only a gimmick. Next, Streiff and Dundes (2017) mentioned that Moana might still depict gender stereotypes, yet the movie focuses more on how Moana seeks independence from her father's shadow. Starting from these, this present study undertakes the research on these three movies to observe the main characters' roles of the movies and to focus on the princess character in viewing the independence of the princesses along with the story.

\section{METHOD OF THE STUDY}

This study attempts to investigate three new Disney princess movies, that is Tangled (2010), Frozen (2013), Moana (2016). All these movies win and are nominated for various prestigious awards; Tangled was nominated 41 times and won 9 awards, Frozen was nominated 57 times and won 79 awards, and Moana was nominated 82 times and won 17 awards (IMDb, 2017). These three movies are believed to represent women as independent and are considered breaking traditional gender stereotypes (Brockmann, 2014; Khalid, 2015; Streiff and Dundes, 2017). The three movies are also depicted in the form of musicals. The main characters' roles in these movies are analyzed utilizing the theory of characters of fairy tales (Propp, 1968), detailing in their actual roles in the stories. Then, the role of princess characters in the movies is investigated by employing the theory of feminism (Tyson, 2006) to prove whether the princesses are already independent as what Disney expects in the making of the movies.

\section{ANALYSIS}

Tangled (2010) is a movie whose story is adapted from Grimm Brother's fairy tale Rapunzel (Khalid, 2015), but with a different line of the story. The plot of the movie tells about the lost princess named Rapunzel Corona who was abducted by Mother Gothel as a baby due to her hair's ability to heal and made Mother Gothel be forever young. Mother Gothel kept Rapunzel in a hidden tower in the middle of the forest so that the King and the Queen could not find her. Mother Gothel acted as her actual mother so that she would not be suspicious. In commemorating the princess' disappearance, the King and the Queen released thousands of lanterns in Rapunzel's birthday hoping she would return home. In her eighteenth's birthday. Rapunzel, who was curious about the appearance of the floating lights, asked for Mother Gothel's permission to see the lanterns up close, yet Mother Gothel refused since the lanterns 
were released from the palace, Rapunzel's actual home. Unexpectedly, a thief namely Flynn Rider hid in Rapunzel's hidden tower after stealing her crown from the palace. Rapunzel seized the crown and attempted to make the deal with Flynn to bring her to the palace for seeing the lanterns. Flynn initially refused since he thought it was not his business to help the girl out, yet he really needed the crown. Thus, he agreed to bring Rapunzel to the palace to see the lantern then brought her back to the tower.

Frozen (2013) is an adaptation of Hans Christian Andersen's Snow Queen (Streiff and Dundes, 2017), yet, similar to Tangled, has a different storyline. The movie depicts a story of two sisters, Queen Elsa and Princess Anna of Arendelle. Elsa had the magical power of freezing things around her. When they were younger, they often played with Elsa's power yet one day, an accident occurred to Anna which caused her heart to be frozen due to Elsa's power. Because of this, the King and the Queen isolated Elsa in a locked room and Anna forgot about Elsa's magical power. The King and the Queen then left the palace and died in the middle of the trip. The sisters then grew up and Elsa was crowned into the Queen. Meanwhile, on the same day, Anna met Prince Hans of the Southern Isles whom then she immediately fell in love too. She asked her elder sister's permission to marry him, yet Elsa refused since they only met once. Anna kept pushing Elsa then all of sudden, Elsa could not control her anger then froze the entire kingdom into perennial winter. Being ashamed and afraid, Elsa escaped from the palace. Anna, who worried about her sister, attempted to find Elsa and asked Prince Hans to lead the kingdom while she went. In the middle of the search, Anna met a mountaineer named Kristoff Bjorgman whom eventually she asked the assistance in finding her sister. Kristoff initially rejected the offer, yet finally accepted since Anna buys him the necessities he needed for the long trip in the winter.

Moana (2016) is a movie which tells about the story of a daughter of Motunui's chief named Moana Waialiki who was chosen by the ocean to return the heart of Te Fiti, the Mother Island goddess. The heart was initially stolen by Maui, the demigod of earth and sky. While going back home, Maui was intercepted by Te Kā, the demon of earth and fire, who was at the end of the story is acknowledge as Te Fiti's alter ego. During the encounter, Maui lost the heart into the depth of the ocean, which thousand years later was brought by the ocean to Moana. The damage of Te Kā then reached Motunui and Moana really concerned about it. She asked her father's permission in returning the heart, but her father objected her departure, yet her grandmother commanded her to leave sooner. In returning the heart, she should first meet Maui so that he could be the one who was responsible for giving the heart back to Te Fiti. Moana then encountered Maui on a deserted island. She asked him to give the heart back, but he refused. After being persuaded by Moana that he would become the hero of humankind, Maui accepted the challenge to return the heart of Te Fiti.

From the story of the three movies above, a similar plot can be drawn. Tangled, Frozen, and Moana basically narrate about a princess who attempted to find someone 
or something in order to return the condition like it was before. In accomplishing the mission, the princess was assisted by a man that she had never encountered previously. The princess requested the man to help her in accomplishing her quest. The man initially refused in following the princess in her journey since he considered the quest was none of his business. However, with the princess' persuasion, the hero was willing to help her in resolving her quest. Meanwhile, in accomplishing the quest, the princess dealt with the villain who exerted to gain the advantage from the princess, be it the power or the entity possessed by the princess. In the end, the villain failed to obtain the advantage from the princess and both the princess and the hero saved the day.

Based on the theory of fairy tale characters (Propp, 1968), it can be summarized that there are three main characters in Tangled, Frozen, and Moana. The main characters are a princess, a hero, and a villain. The princess in the three movies is the woman who conducts the quest while being assisted by the hero. The princesses of the movies are Rapunzel Corona (Tangled, 2010), Princess Anna of Arendelle (Frozen, 2013), and Moana Waialiki (Moana, 2016). These princesses have different quest to complete. For example, Rapunzel Corona (Tangled, 2010) began her adventure from her curiosity of the appearance of floating lights every year on her birthday, yet her false mother, Mother Gothel, forbade her for going. This appears in the following conversation.

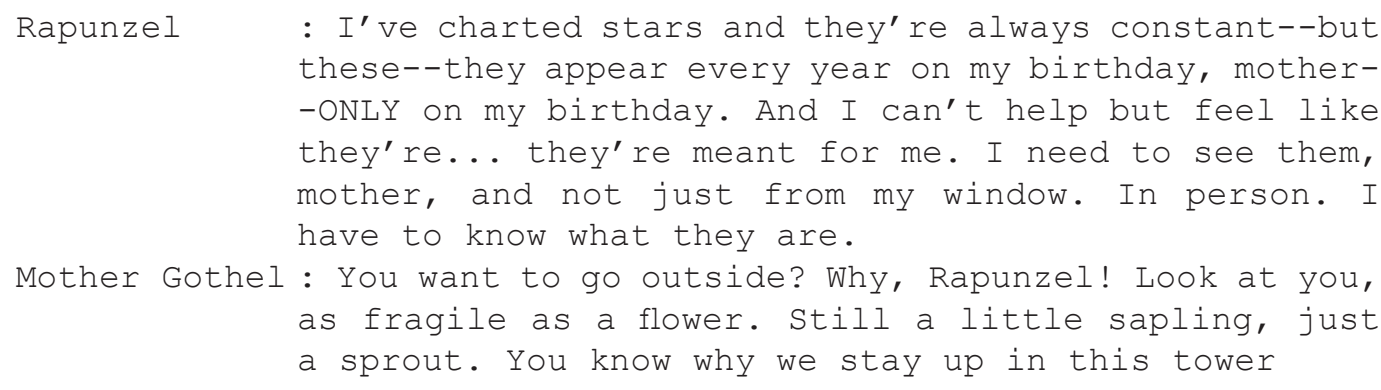

Different from Rapunzel, Princess Anna of Arendelle (Frozen, 2013) began her adventure due to her sister's, Queen Elsa of Arendelle, departure from the palace. This is depicted in the following conversation.

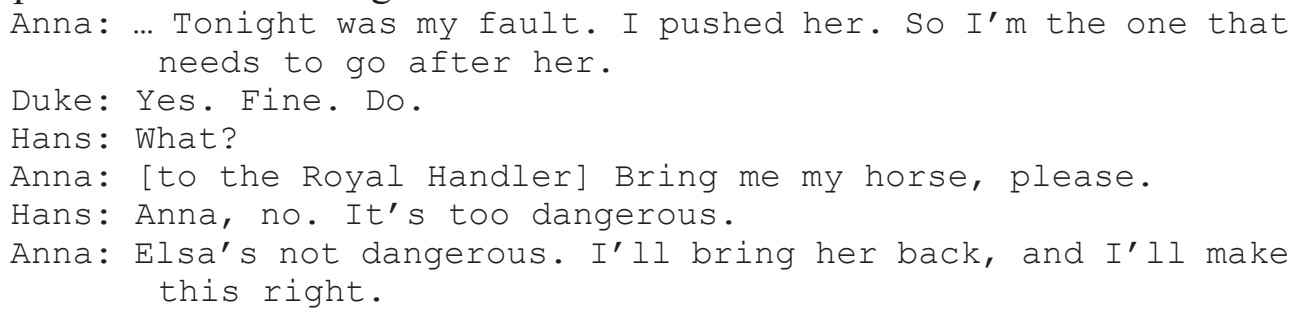

Moana Waialiki (Moana, 2016) has a different beginning for her quest. She started her adventure at the behest of her grandmother at the end of her life to find Maui the Demigod to bring back the heart of Te Fiti. The order can be found in the following conversation. 


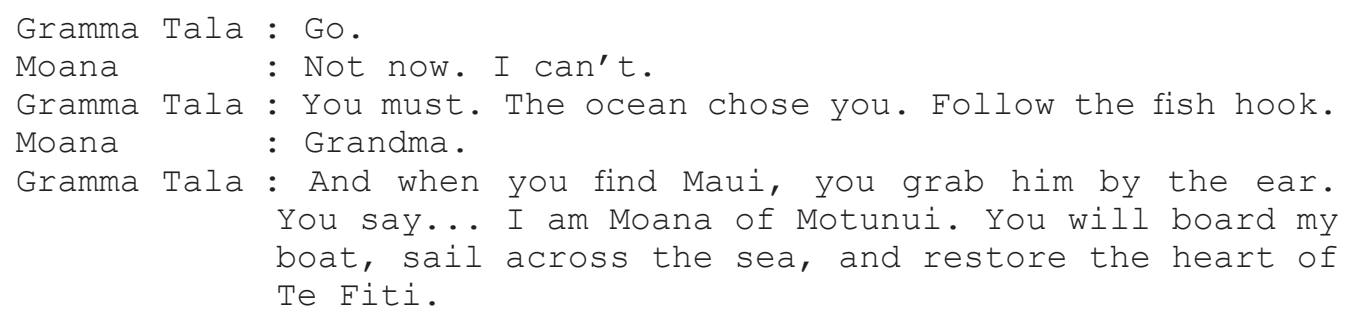

From the conversations above, it can be deduced that all the princesses aimed to go on a different quest. They dispatched themselves from their home to achieve what they aim, be it due to curiosity or concern, and they initially were not helped by anyone from their home. Therefore, all these princesses are depicted as the ones who are independent, strong, and brave, despite their hesitation on their own ability in the middle of the quest. These characters of princess are dissimilar from the ones Disney previously creates, for instance, Cinderella (1950), Snow White (Snow White and the Seven Dwarfs, 1937), and Aurora (Sleeping Beauty, 1959), in which the princesses are dependent on men, require some magical power in achieving something, and domesticobeying the traditional gender role (Barber, 2015). Rapunzel, Anna, and Moana do not act like the former princesses and they tend to break the traditional rules given to them.

Then, the hero in the movies is the man who has never been encountered by the princess beforehand that henceforth being requested to assist the princess in her quest. The heroes of the movies are Flynn Rider (Tangled, 2010), Kristoff Bjorgman (Frozen, 2013), and Maui the Demigod (Moana, 2016). In the movie, Rapunzel, who caught Flynn Rider in her castle, tried to convince him to help her in exchange for his satchel back. It is depicted in the following conversation.

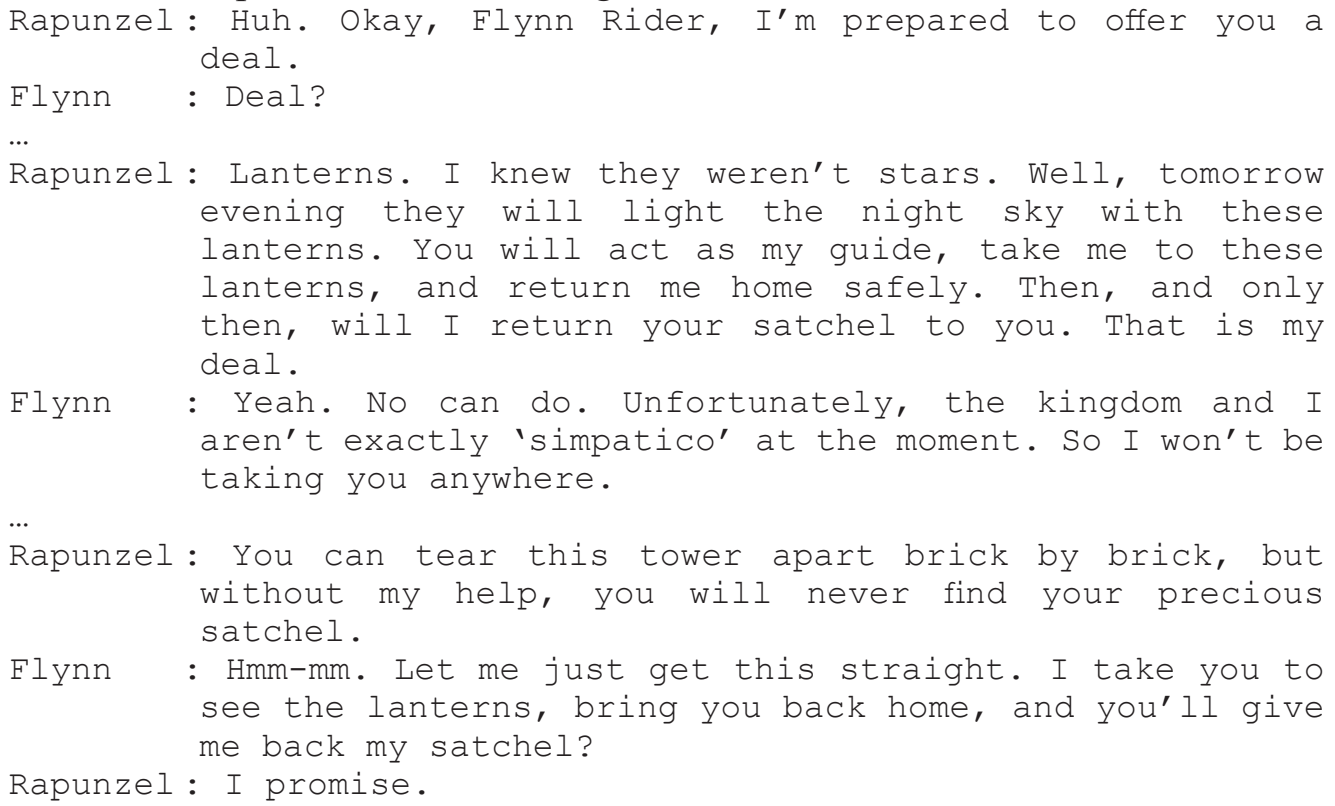

In the different movie, Anna made a deal with Kristoff, whom she met at Wandering Oaken's Trading Post, to bring her to the North Mountain to find her sister with a sack of supplies and a bag of carrots in exchange. It can be seen in the following 
conversation.

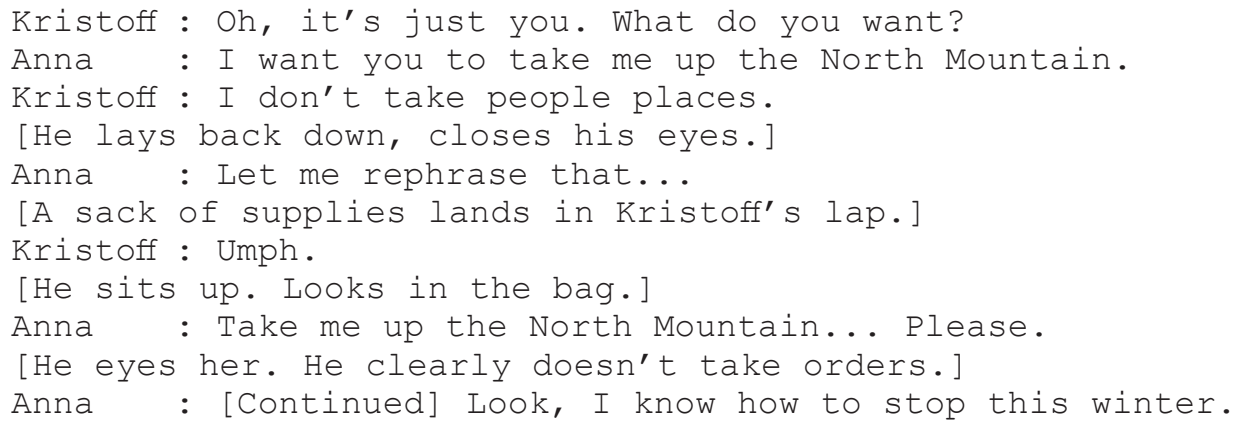

Also, in a different movie, Moana forced Maui to bring back the heart of Te Fiti. It can be seen in the following conversation.

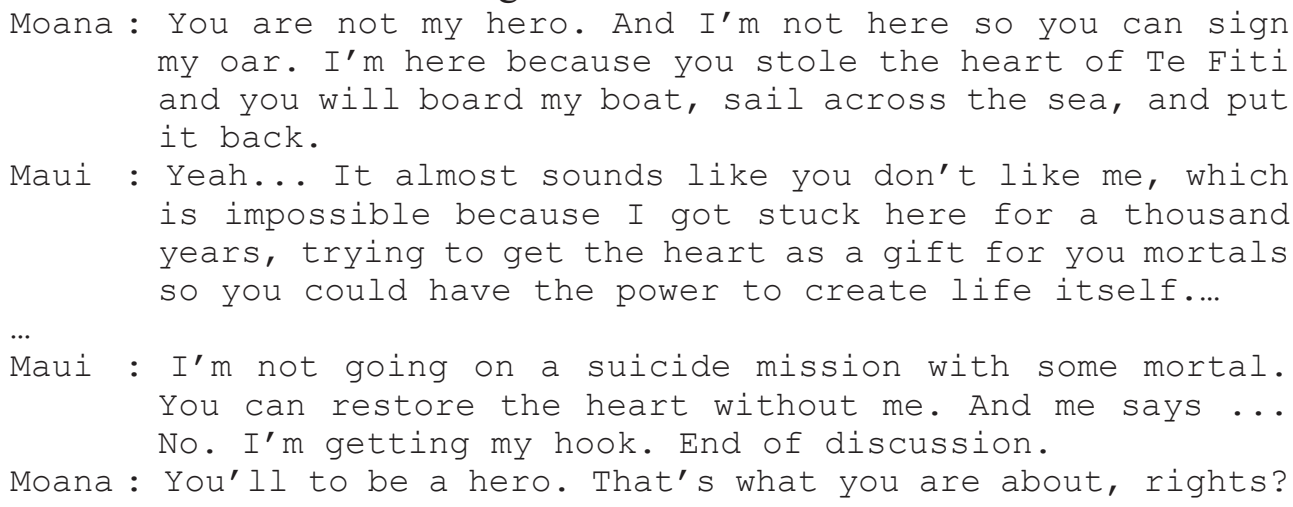

The similarity of these heroes is that they have never met the princesses before the quest happens. The heroes and the princesses encounter in the unexpected circumstances, yet the princesses are sure of inviting the strangers into their journey. The princesses believe that the men they just met at that time can assist them in completing their mission. Another similarity is that they initially decline the princesses' request in joining them in their quest. These heroes consider that the quest has nothing to do with them, thus they do not have to involve themselves in the quest. However, due to the princesses' persuasion of resources and fame, the heroes agree to participate in the princesses' journey. What is interesting from the heroes in the three movies is that unlike the former Disney princess like Eric (The Little Mermaid, 1989) or Prince Charming (Cinderella, 1950) who tend to be superior over the princesses since they believe to make the princesses' wishes come true (Maity, 2014), the heroes in these movies initially do not consider their princesses as someone to be saved and to take control over, instead they consider their princesses as troublesome and too excited about their journey. They do not think that they can fulfill the princesses' wishes that is why they refuse to join in the princesses' journey in the beginning, although they eventually accept the request at the end of the long arguments.

Meanwhile, the villain is the one in the movies who attempts to seize the advantage of the princess. The villains of the movies are Mother Gothel (Tangled, 2010), Prince Hans of the Southern Isles (Frozen, 2013), and Te Kā (Moana, 2016). Mother Gothel (Tangled, 2010) acted as Rapunzel's mother to have her magical hair like her own, 
which is depicted in the narration, "The kingdom searched and searched but they could not find the princess. For deep within the forest, in a hidden tower, Gothel raised the child as her own." (Lamperouge, 2017:2). Meanwhile, Prince Hans of the Southern Isles (Frozen, 2013) acted as Anna's lover until he opened up his actual intention, like what is depicted in the following conversation.

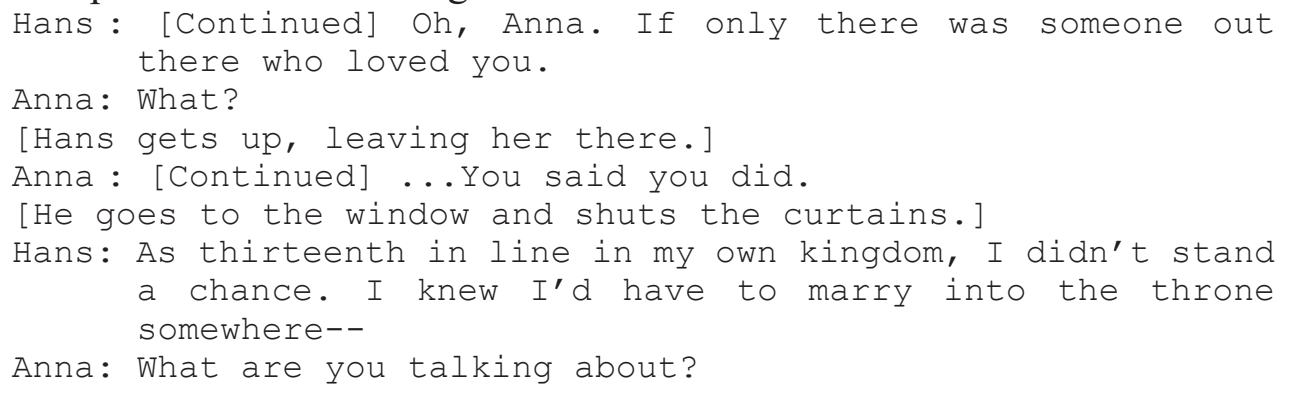

Different from Mother Gothel and Prince Hans, Te Kā (Moana, 2016) was formed from Te Fiti whose heart was stolen by Maui, which is depicted in the following narrative, "Te Fiti. Her heart has the greatest power ever known. It could create life itself.... And one day, the most daring of them all voyage across the vast ocean to take it. ... And his name was Maui. But without her heart, Te Fiti began to crumble, giving birth to a terrible darkness." (Clements, 2016:2).

What is worth noting is that the villains in Tangled and Frozen pretend to be the false hero at the beginning of the story. Both villains, Mother Gothel and Prince Hans, enact themselves as the ones who will protect the princess at any cost, will assist them in any condition, and will save them from any difficulties. The innocent princesses believe them since the villains work as the mother (Mother Gothel) and the lover (Prince Hans), by whom the princesses consider as the lifesavers. By acting this way, both of them expect to gain the advantage from the princesses, in which Mother Gothel requires Rapunzel's hair for her youthful appearance and Prince Hans requires marriage with Anna for the acquisition of her kingdom Arendelle. Meanwhile, in Moana, Te Kā is not actually the villain. She was initially the goddess of life, Te Fiti, whose heart was stolen by Maui, the hero in the movie. Thus, the advantage she attempts to capture from Moana is actually her own possession. However, the endings of the villains are different. Both Mother Gothel and Prince Hans fail to earn what they desire while Te Kā gains her heart back to then change her back into Te Fiti.

From the previous explanation about the princess character in Tangled, Frozen, and Moana, it can be deduced that the princesses in these movies are extremely dissimilar from the former Disney princesses since the princesses here are considered to breaking the traditional gender roles, in which women traditionally are depicted as "emotional (irrational), weak, nurturing, and submissive." (Tyson, 2006:85) In the movies, the princesses demonstrate that they are strong enough to conduct the mission they attempt to accomplish, they are decisive in deciding what they want and do not want to do, they have the power and will to do anything to achieve their aim, and 
they tend to rescue and face the problem themselves rather than being rescued like the former princesses Disney has. Their strength, decisiveness, and independence are shown in the way they decide to dispatch themselves from their home for a mission they pursue, how they make a deal with some stranger they have never encountered previously, and how they make some decision in reaching their objectives. Strong, decisive, and independent are considered as men's qualities in the traditional gender roles, the qualities that are not considered to be in women's traits, yet these princesses keep depicting these qualities from the beginning to the end of the story. Even if they are being assisted by the men in accomplishing their quest, yet they miraculously encounter the villains themselves at the end of the movie.

However, how Disney really liberate their latter princesses to be independent becomes another question. These movies indeed depict women as the leading character and the women in these movies have the power and decision in conducting the quest they desire to do. Yet, let us not forget the men besides these women who accompany them along the journey. These extraneous men who have nothing to do with the quest are requested or even, to be more emphasizing, are insisted to join the journey by these princesses, which can be considered as peculiar for a woman asking a stranger out to go somewhere doing something out of his will. Apparently, these princesses have not sufficient self-confidence in conducting the quest alone, they still consider themselves to need any help from a man.

What the princesses encountered is not surprising since women generally will reduce their competence (Peterson, 2010). They often perceive themselves in anything men are capable of as not sufficient to actually compare their own abilities with what men acquire. Hence, women have lack confidence in being able to comprehend that they are actually as capable as men in doing or receiving anything, such as being promoted to the higher position (Kay and Shipman, 2014; Neal, et al., 2008). These results in the perspective of women as the less effective leaders and men are considered better in making a decision (Rizzo \& Mendez, 1990). This might be respected as the weakness of these movies. Even if Disney attempts to establish some breakthrough in the creation of its latter princesses by breaking the traditional gender roles, yet Disney still does not let its princesses walk in the wood or pass across the ocean alone. Disney still believes that these princesses should be accompanied along their journey, and the novel men are considered suitable for tagging along the princesses' journey.

\section{CONCLUSION}

In Tangled (2010), Frozen (2013), Moana (2016), there are three main character's roles that prominently appear. The roles are the princess, the hero, and the villain. Through these movies, Disney has a serious attempt in representing its princesses as independent women, signified by the depiction of the princess role in these movies. The princesses in these movies are the leading role, and they do not rely 
on men to be saved. However, although they are not rescued by the heroes-they instead try to save other people, they still require the heroes' assistance in accomplishing the quest they desire to resolve. This indicates that even though Disney strives to liberate its princesses to break the traditional gender role, yet the princesses are not truly free in conquering their own lack of self-confidence.

\section{REFERENCES}

Barber, M. (2015). Disney's female gender roles: The change of modern culture. (Honors Thesis). Indiana State University, Indiana, USA.

Brockmann, M. (2014). Do you want to be a Feminist? Frozen (2013). Kino, 1-18. Retrieved from www.medienobservationen.lmu.de/artikel/kino/kino_pdf/ Brockmann_Frozen.pdf.

Clements, R. (2016). Moana. Published manuscript. Retrieved from https://www. scripts.com/script/moana_1224.

Erum, T. (n.d.). The history of gender ideology in Brothers Grimm's fairy tales. Retrieved from https://www.academia.edu/8349624/The_history_of_gender_ideology_ in_brothers_grimms_fairy_tales.

Gazda, C. (2015). The (de)evolution of the Disney princess. Dissenting Voice, 4(1), 29-46.

Neal, G., et al. (2008). By the way... Self-confidence-the key to success? Studies in Learning, Evaluation Innovation, and Development, 5(1), 45-58.

IMDb. (2017). Frozen (2013): Awards. Retrieved from http://www.imdb.com/title/ tt2294629/awards.

. (2017). Moana (2016): Awards. Retrieved from http://www.imdb.com/title/ tt3521164/awards.

. (2017). Tangled (2010): Awards. Retrieved from http://www.imdb.com/title/ tt0398286/awards.

Kay, K, Shipman, C. (2014). The confidence gap. Retrieved from https://www. theatlantic.com/magazine/archive/2014/05/the-confidence-gap/359815/.

Khalid, M. (2015). A feminist study of Tangled. European Academic Research, 3(2), $1833-1845$.

Lamperouge, N. (2017). Tangled. Published manuscript. Retrieved from https://www. scribd.com/document/343258609/213024233-Script-for-Tangled-pdf.

Lee, Jennifer. (2013). Frozen: Final shooting draft. Published manuscript. Retrieved from https://www.scribd.com/document/356600981/frozen-screenplay-pdf.

Maity, N. (2014). Damsels in distress: A textual analysis of gender roles in Disney princess films. IOSR Journal of Humanities and Social Science, 19(10), 2831.

Morrison, D. (2014). Brave: A feminist perspective on the Disney princess movie. (Bachelor Thesis). California Polytechnic State University, California, USA.

$\mathrm{Ng}, \mathrm{V}$. (2013). How Disney princesses became a multi-billion dollar brand. Retrieved from http://www.mcngmarketing.com/how-disney-princesses-became-amulti-billion-dollar-brand/\#.WibKuDcxW00.

Peterson, H. (2010). The gendered construction of technical self-confidence: Women's negotiated positions in male-dominated, technical work settings. International 
Journal of Gender, Science and Technology, 2(1), 65-88.

Propp, V. (1968). Morphology of the folktale (2nd ed.). Texas: University of Texas Press.

Renkema, J. (2004). Introduction to discourse studies. Amsterdam: John Benjamins Publishing Co.

Rizzo, A. M., \& Mendez, C. (1990). The integration of women in management: A guide for human resources and management development specialists. New York: Quorum.

Streiff, M., Dundes, L. (2017). From shapeshifter to lava monster: Gender stereotypes in Disney's Moana. Social Sciences, 6(91), 1-12.

. (2017). Frozen in time: How Disney gender-stereotypes its most powerful princess. Social Sciences, 6(38), 1-10.

Tyson, L. (2006). Critical theory today: a user-friendly guide (2nd ed.). New York: Routledge.

Wohlwend, K. E. (2007). Damsels in discourse: girls consuming and producing identity texts through Disney princess play. Retrieved from http://www.wstudies. pitt.edu/wiki/images/7/79/Damsels_in_discourse_girls_consuming_ and producing_identity_texts_through_disney_princess_play.pdf. 